Tropical Journal of Pharmaceutical Research April 2021; 20 (4): 687-693

ISSN: $1596-5996$ (print); 1596-9827 (electronic)

(C) Pharmacotherapy Group, Faculty of Pharmacy, University of Benin, Benin City, 300001 Nigeria.

Available online at http://www.tjpr.org

Original Research Article

http://dx.doi.org/10.4314/tjpr.v20i4.4

\title{
Demethoxycurcumin inhibits the growth of human lung cancer cells by targeting of PI3K/AKT/m-TOR signalling pathway, induction of apoptosis and inhibition of cell migration and invasion
}

\author{
Yunlong Chen ${ }^{1,2}$, Mianhua $\mathrm{Wu}^{1 *}$ \\ ${ }^{1}$ First Clinical Medical College, Nanjing University of Chinese Medicine, Nanjing, Jiangsu Province 210023, ${ }^{2}$ Department of \\ Oncology, Rudong Hospital of Traditional Chinese Medicine, Nantong City, Jiangsu Province 226400, China
}

*For correspondence: Email: fajizo@163.com; Tel/Fax: 0086--25-86798167

Sent for review: 17 December 2020

Revised accepted: 19 March 2021

\begin{abstract}
Purpose: To determine the antitumor effect of demethoxycurcumin on lung cancer cells, as well as its effect on PI3KJAKT/m-TOR signalling, cellular apoptosis, cell migration and cell invasion.

Methods: Cell viability was determined using 3-(4,5-dimethylthiazol-2-yl)-2,5-diphenyl tetrazolium bromide (MTT) assay, while AO/EB and annexin V/PI staining assays were used for apoptosis analysis in demethoxycurcumin-treated A-549 lung cancer cells. Transwell chamber assay was used to determine the effect of demethoxycurcumin on migration and invasion of A-549 cells. The expression levels of PIJK/AKT/m-TOR signalling and apoptosis-associated proteins in A-549 cells postdemethoxycurcumin treatment were determined by Western blotting assay.

Results: Demethoxycurcumin markedly inhibited the proliferation of A-549 cells in a dose- and timereliant fashion. The antiproliferative effect of demethoxycurcumin occurred via stimulation of apoptosis. The expression levels of Bax, Caspase-3 and Caspase-9 increased significantly, while Bcl-2 was significantly decreased in A-549 cells post-demethoxycurcumin treatment. Demethoxycurcumin substantially inhibited migration and invasion of A-549 cells, and blocked PI3KJAKT/m-TOR signalling pathway in these cells.

Conclusion: Demethoxycurcumin induces anticancer effects on A-549 cells via targeting PIJKJAKT/mTOR signalling pathway. It induces cellular apoptosis and inhibits migration and invasion of A-549 cells. Thus, it is a promising anti-lung cancer agent.
\end{abstract}

Keywords: Lung cancer, Demethoxycurcumin, Apoptosis, Cell migration, Cell invasion

\begin{abstract}
This is an Open Access article that uses a fund-ing model which does not charge readers or their institutions for access and distributed under the terms of the Creative Commons Attribution License (http://creativecommons.org/licenses/by/4.0) and the Budapest Open Access Initiative (http://www.budapestopenaccessinitiative.org/read), which permit unrestricted use, distribution, and reproduction in any medium, provided the original work is properly credited.
\end{abstract}

Tropical Journal of Pharmaceutical Research is indexed by Science Citation Index (SciSearch), Scopus, International Pharmaceutical Abstract, Chemical Abstracts, Embase, Index Copernicus, EBSCO, African Index Medicus, JournalSeek, Journal Citation Reports/Science Edition, Directory of Open Access Journals (DOAJ), African Journal Online, Bioline International, Open-J-Gate and Pharmacy Abstracts

\section{INTRODUCTION}

Cancer is a serious health problem that affects a significant percentage of the human population globally. Notwithstanding recent advances in cancer diagnosis and treatment, the prevalence of cancer and its associated mortality have continued to pose serious challenge to doctors and researchers. Lung cancer (LC) is a serious lung disorder that accounts for high number of 
deaths in men and women across the globe [1] In the year of 2013 alone, nearly 1.8 million LC cases and 1.6 million deaths were reported worldwide [2]. The incidents of LC are expected to double by the year 2035 [3]

Small cell lung cancer and non-small cell lung cancer are two distinct histological subtypes of LC. Non-small cell lung cancer (subtypes: adenocarcinoma, squamous cell and large cell carcinoma) accounts for nearly $85 \%$ of total LC cases, $40 \%$ of which are adenocarcinomas [4]. Globally, the incidence of LC is higher in men (1 out of 18) than in women (1 out of 51). The incidence of LC among women is expected to rise in the coming years. Women suffering from LC show better prognosis, improved survival and better treatment responses than their male counterparts [5-8]. The overall 5-year survival of LC patients is less than $18 \%$. Therefore, LC is a lethal health hazard which needs to be addressed through better management and chemotherapeutic approaches. Natural products are enormous chemical entities with huge medicinal and biological potential [9-12]. Naturally-occurring turmeric has been used as a spice in various South Asian countries for ages. Turmeric has remained an integral part of traditional systems of medicine in China and India [13]. Different extracts prepared from turmeric have been reported to contain bisdemethoxycurcumin, demethoxycurcumin and curcumin, all of which are collectively called curcuminoids. Demethoxycurcumin is a betadiketone similar to curcumin in structure, with one less methoxy group. Apart from its presence in turmeric, demethoxycurcumin is a major constituent of beverages. Moreover, it has been isolated from Curcuma xanthorrhiza and Curcuma zedoaria. It has been reported that demethoxycurcumin has anti-inflammatory, antineoplastic and anticancer properties [14-18]. Moreover, it has been reported that demethoxycurcumin exerts potential antitumor activity through modulation of several molecular targets. In addition, demethoxycurcumin has been shown to produce pro-apoptotic and proautophagic effects against several human cancer cell lines. The present study was undertaken to investigate the anticancer potential of demethoxycurcumin on LC cell line, as well as its effect on cellular apoptosis, PI3K/AKT/m-TOR signalling, cell migration and cell invasion.

\section{EXPERIMENTAL}

\section{Cell proliferation assay}

The effect of demethoxycurcumin on the proliferation of A-549 LC cells was determined with MTT assay. The A-549 LC cells were cultured in 96-well plates at a density of $5 \times 10^{4}$ cells per well at $37^{\circ} \mathrm{C}$ for $24 \mathrm{~h}$. Then, the wells were treated with varying concentrations of demethoxycurcumin $(10,20,40$ and $80 \mu \mathrm{M})$ for 48 and $72 \mathrm{~h}$ at $37{ }^{\circ} \mathrm{C}$ in a $5 \% \mathrm{CO}_{2}$ incubator. Untreated cells served as control. Thereafter, 10 $\mu \mathrm{L}$ of MTT was added to each well, followed by incubation, first for $15 \mathrm{~min}$, and then for additional $4 \mathrm{~h}$. Finally, the formazan crystals formed were dissolved using DMSO, and absorbance was read at $450 \mathrm{~nm}$ in a microplate reader (BioRad, Segrate, Italy).

\section{Determination of apoptosis using AO/EB dual fluorescent dye}

Apoptotic cell death in A-549 LC cells was investigated using $A O / E B$ dual staining and annexin V/PI staining assays. The cells were seeded in 96-well plates and treated with demethoxycurcumin at different concentrations viz 20, 40 and $80 \mu \mathrm{M}$. Post-treatment, the cells were trypsinized using trypsin, and $20 \mu \mathrm{L}$ of cell suspension was placed on glass slide, followed by exposure to AO/EB dual fluorescent staining solution $(100 \mu \mathrm{g} / \mathrm{mL})$. The glass slides were then covered with coverslips. Cellular morphology was examined in 500 cells in 20 min using a fluorescent microscope (OLYMPUS, Japan).

\section{Annexin V/PI staining assay}

In the analysis of apoptosis using annexin V/PI, A-549 LC cells were plated in 96-well plates at a density of $2 \times 10^{4}$ cells per well. The wells were incubated with different concentrations of demethoxycurcumin. i.e. 20,40 and $80 \mu \mathrm{M}$ for 24 h. Thereafter, the cells were rinsed with PBS and fixed with $10 \%$ formaldehyde, followed by addition of annexin V/PI solution. Then, the cells were examined under a fluorescence microscope.

\section{Transwell assay}

The LC A-549 cells at $>70 \%$ confluence were exposed to varying concentrations of demethoxycurcumin viz 20, 40 and $80 \mu \mathrm{M}$ for 48 h. Transwell chambers were utilized for determination of cell migration. The upper chamber contained transfected A-549 cells in RPMI-1640 culture medium without serum, while the lower chamber contained $600 \mu \mathrm{L}$ of culture medium with $10 \%$ FBS (Corning Incorporated, NY, United States). The transwell chambers were incubated for $12 \mathrm{~h}$, followed by fixation of the cells with alcohol for $10 \mathrm{~min}$ at $4{ }^{\circ} \mathrm{C}$. Nonmigrated cells were discarded, while migrated cells were stained using crystal violet at $25^{\circ} \mathrm{C}$ for 
$10 \mathrm{~min}$. The migrated cells were then examined under a light microscope (TS100; Nikon Corporation, Tokyo, Japan) under x200 magnification and photographed. For estimation of the effect of demethoxycurcumin on cell invasion, a similar method was operated except for a 6-h pre-coating of transwell chambers with Matrigel.

\section{Western blotting assay}

The A-549 LC cells were treated with varying doses of demethoxycurcumin viz 20, 40 and 80 $\mu \mathrm{M}$. Total protein was extracted from the cells via lysis with RIPA buffer, and the protein concentration of each lysate was determined using BCA protein assay method. Then, equal amounts of protein (40 $\mu \mathrm{g}$ portions) were separated using SDS-PAGE, followed by transfer of the separated proteins to PVDF membranes. Thereafter, the membranes were blocked by incubation with $5 \%$ skimmed milk powder solution in Tris-buffered saline tween (TBST) for about $1 \mathrm{~h}$. The blocked membranes were then incubated in the dark at $4{ }^{\circ} \mathrm{C}$ with primary antibodies against Bcl-2, Bax, Caspase-3, Caspase-9, PI3K, AKT and m-TOR. Post-primary antibody treatment, the membranes were incubated with horse radish peroxidase-coupled secondary antibody for $1 \mathrm{~h}$ at $4{ }^{\circ} \mathrm{C}$, followed by washing thrice with TBST. Finally, the protein signals were observed with an advanced chemiluminescent agent.

\section{Statistical analysis}

Each assay was repeated thrice. The data are expressed as mean \pm standard deviation (SD). Statistical analysis was done using Unpaired Student's t-test. Values of $p<0.05$ were considered as indicative of statistically significant differences.

\section{RESULTS}

\section{Effect of demethoxycurcumin on viability of A-549 LC cells}

The effect of demethoxycurcumin on the viability of A-549 cells is shown in Figure 1. Demethoxycurcumin produced potent dose- and time-reliant inhibition of viability of A-549 cells. It was observed that the percentage viability values at $0,10,20,40$ and $80 \mu \mathrm{M}$ were 100,90 , 70,42 and 17, after $48 \mathrm{~h}$ of demethoxycurcumin exposure. The percentage viability values at same drug concentrations after $72 \mathrm{~h}$ of exposure were 90, 82, 60, 30 and 10, respectively (Figure 2). Thus, demethoxycurcumin exerted antiproliferative effects on the cells.

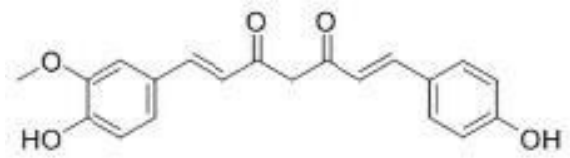

Figure 1: Chemical structure of demethoxycurcumin

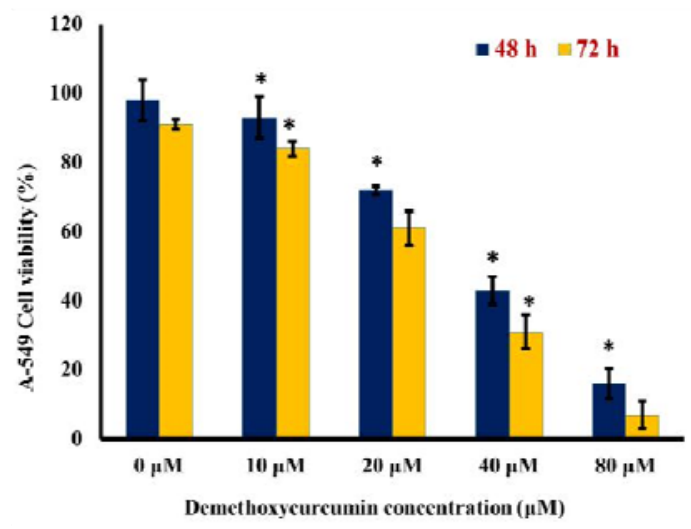

Figure 2: Graphical representation of results from MTT assay. Demethoxycurcumin showed dose- and time-dependent inhibition of A-549 cell viability. The experiments were done in triplicate, and data are presented as mean $\pm \mathrm{SD}$; ${ }^{*} p<0.05$, compared with $72 \mathrm{~h}$ value

\section{Apoptotic effects of demethoxycurcumin in A-549 cells}

Demethoxycurcumin-treated A-549 LC cells were stained with $A O / E B$. The AO/EB staining revealed no sign of apoptosis in the negative control group. However, on drug exposure, AO fluorescent crescent-shaped yellow-green cells (early-stage apoptotic cells), orange EB fluorescent cells (late-stage apoptotic cells) and orange-red fluorescent cells (necrotic cells) were seen (Figure 3). These results indicated induction of apoptotic cell death by demethoxycurcumin in A-549 LC cells. Therefore, Annexin V/PI staining assay was used to quantify apoptosis in demethoxycurcumin-treated A-549 cells. The results indicated dose-dependent apoptosis of A-549 LC cells. At concentrations of $0,20,40$ and $80 \mu \mathrm{M}$, the percentages of annexin $\mathrm{V}+/ \mathrm{PI}-$ apoptotic cells were 4, 18, 24 and 28, respectively, while the percentages of annexin $\mathrm{V}+/ \mathrm{PI}+$ apoptotic cells were 9, 23, 27 and 33\% (Figure 4). Thus, demethoxycurcumin exerted dose-reliant increase in the percentage of apoptotic cells. Furthermore, western blotting analysis of demethoxycurcumin-treated A-549 LC cells indicated marked upregulation of proapoptotic proteins and downregulation of antiapoptotic protein. The expression levels of Caspase-3, Caspase- 9 and Bax were

Trop J Pharm Res, April 2021; 20(4): 689 
upregulated dose-reliantly, while $\mathrm{Bcl}-2$ was downregulated (Figure 5). Thus, AO/ETBR dual staining, annexin V/PI staining and western blotting confirmed that demethoxycurcumin induced apoptosis in A-549 LC cells.

Inhibitory effect of demethoxycurcumin on migration and invasion of A-549 cells

Cell migration and invasion in A-549 LC cells treated with demethoxycurcumin $(20,40$ and 80 $\mu \mathrm{M})$ were estimated via transwell chambers assay. The cell migration was markedly and dose-reliantly inhibited by demethoxycurcumin, when compared to the negative control (Figure 6). Furthermore, the results from transwell chamber assay revealed that the number of invasive cells counted under a light microscope, was reduced significantly with increases in demethoxycurcumin doses (Figure 7).

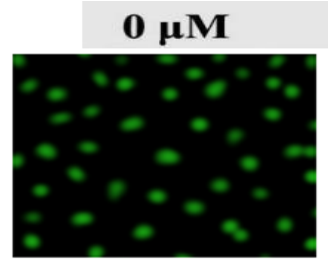

$40 \mu \mathrm{M}$

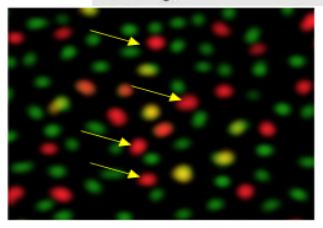

$20 \mu M$

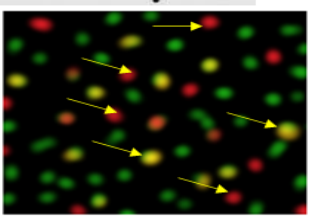

$80 \mu \mathrm{M}$

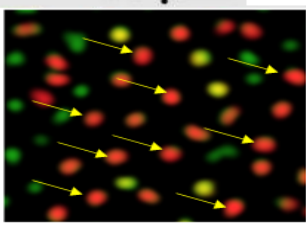

Figure 3: $A O / E B$ staining at specified doses of demethoxycurcumin. The experiments were repeated thrice

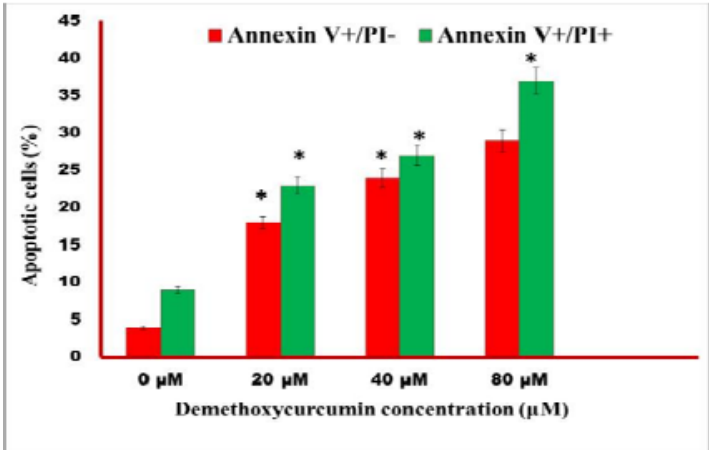

Figure 4: Results of annexin V/PI staining showing percentages of annexin $\mathrm{V}+/ \mathrm{PI}$ - and annexin $\mathrm{V}+/ \mathrm{PI}+$ apoptotic cells. There were dose-dependent increases in the percentage of apoptotic A-549 cells in demethoxycurcumin-treated groups, relative to the control group. The experiments were repeated thrice, and data was presented as mean $\pm \mathrm{SD}$. ${ }^{*} P<0.05$

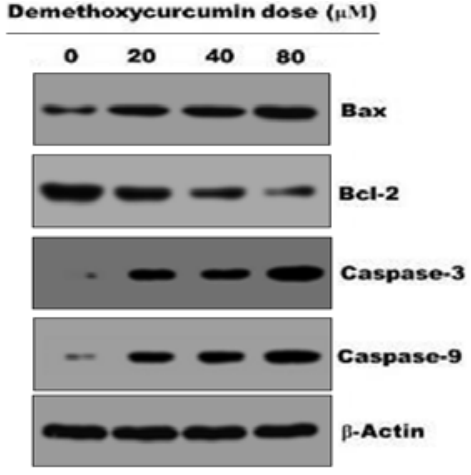

Figure 5: Effect of demethoxycurcumin on protein expressions of Bax, Caspase-3, Caspase- 9 and Bcl-2 in A-549 LC cells, as assayed using western blotting. There were increased protein expressions of proapoptotic Bax, Caspase- 3 and Caspase-9, while the expression of anti-apoptotic $\mathrm{Bcl}-2$ protein was decreased. Each experiment was performed thrice

Inhibitory effect of demethoxycurcumin on $\mathrm{PI3K} / \mathrm{AKT} / \mathrm{m}$-TOR signalling pathway in A549 cells

The PI3K/AKT/m-TOR signalling pathway plays a vital role in regulation of various cancer cell survival processes. The effect of demethoxycurcumin on $\mathrm{PI} / \mathrm{K} / \mathrm{AKT} / \mathrm{m}-\mathrm{TOR}$ signalling pathway in A-549 LC cells were determined using western blotting assay. The results revealed dose-dependent inhibition of the expressions of $\mathrm{PI} 3 \mathrm{~K} / \mathrm{AKT} / \mathrm{m}-\mathrm{TOR}$ signalling pathway-associated proteins. However, there were no changes in the expressions of $\mathrm{PI} 3 \mathrm{~K}$, AKT and m-TOR, while the levels of phosphorylated PI3K, AKT and m-TOR were significantly and dose-reliantly reduced (Figure 8).

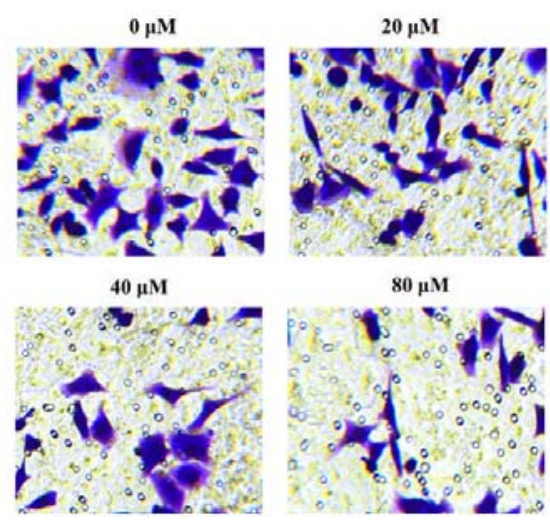

Figure 6: Photomicrograph of migration of A-549 LC cells (negative control and positive ucontrol. Each experiment was repeated thrice 

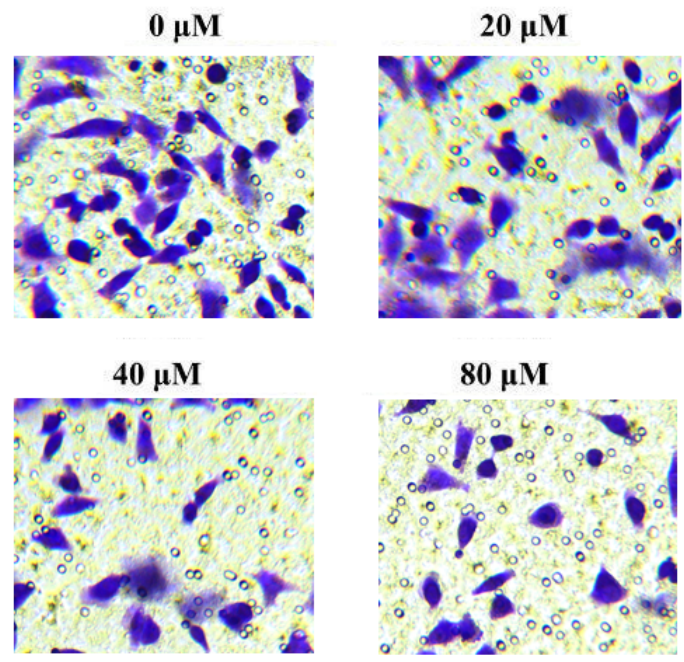

Figure 7: Photomicrograph of invasiveness of negative control and positive control (demethoxycurcumin treated) A-549 LC cells. Each experiment was performed thrice

\section{Demethoxycurcumin dose $(\mu \mathrm{M})$}

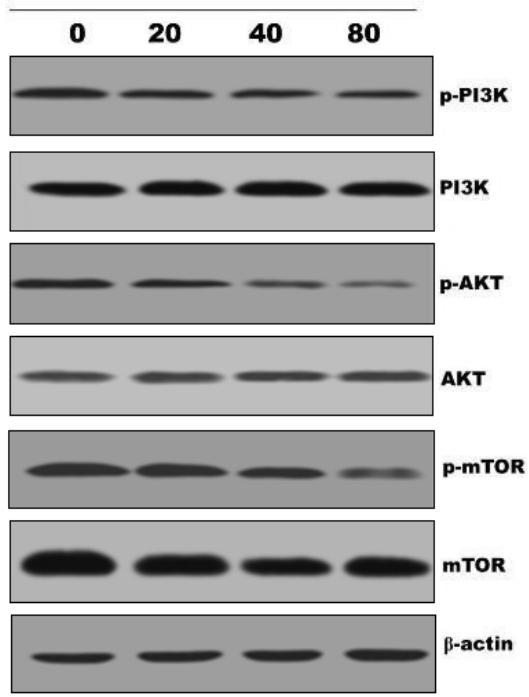

Figure 8: Effect of demethoxycurcumin on the expressions of $\mathrm{PI} 3 \mathrm{~K} / \mathrm{AKT} / \mathrm{m}$-TOR signalling pathway proteins in A549 cells, as determined using western blotting. Each experiment was repeated thrice

\section{DISCUSSION}

Apoptosis is a natural process for programmed elimination of cells as a result of cell injury or cell malfunction [19]. This process is non-toxic in nature, and does not affect nearby growing cells or tissues. Multicellular organisms use apoptosis extensively for maintaining tissue, organ or overall health due to the fact that apoptosis helps in discarding unhealthy, excessive and old cells. Several biochemical events during apoptosis change cell morphology and ultimately induce cell death. These events include membrane blebbing, chromatin condensation, cell shrinkage, DNA fragmentation, nuclear fragmentation and global mRNA decay $[20,21]$.

Apoptosis is a highly regulated and controlled process. Thus, the targeting apoptosis in cancer cells is a useful strategy in cancer therapy. In the current study, the antiproliferative effect demethoxycurcumin was investigated in human lung A-549 cancer cells by studying its effects on the $\mathrm{PI} 3 \mathrm{~K} / \mathrm{AKT} / \mathrm{m}-\mathrm{TOR}$ signaling pathway, cellular apoptosis and cell migration and invasion.

The results revealed that demethoxycurcumin induced dose- and time-dependent inhibition of A-549 cell viability. A previous study showed that demethoxycurcumin induced apoptotic cell death in breast cancer cells [22]. In the present study, demethoxycurcumin stimulated apoptosis in A-549 LC cells by increasing the expression levels of Caspase- 3 and Caspase-9, and decreasing Bcl-2 expression level.

Demethoxycurcumin has been shown to exert anti-migration and anti-invasion effects against PC-3 prostate cancer cells via inhibition of MMP2 [23]. In this study, demethoxycurcumin produced dose-dependent inhibitions of the migration and invasion of LC A-549 cells. The $\mathrm{PI} K \mathrm{~K} / \mathrm{AKT} / \mathrm{m}$-TOR signalling is involved in modulation of key intracellular processes like cell survival, proliferation, cell cycle, apoptosis and cell differentiation.

In this study, demethoxycurcumin induced significant suppression of $\mathrm{PI} 3 \mathrm{~K} / \mathrm{AKT} / \mathrm{m}-\mathrm{TOR}$ signalling pathway via downregulation of key proteins of the pathway. These results are in agreement with the finding that curcumin, a structural analogue of demethoxycurcumin (with an additional methoxy group) induced marked suppressive effects on the PI3K/AKT/m-TOR signalling pathway [24].

\section{CONCLUSION}

The results of this study reveal that demethoxycurcumin significantly suppresses the proliferation of human lung cancer A-549 cells via a mechanism involving inhibition of the $\mathrm{PI} 3 \mathrm{~K} / \mathrm{AKT} / \mathrm{m}-\mathrm{TOR}$ signalling pathway, induction of cellular apoptosis and suppression of cell migration and invasion ability. Thus, demethoxycurcumin is a promising anti-lung cancer agent. 


\section{DECLARATIONS}

\section{Conflict of interest}

No conflict of interest is associated with this work.

\section{Contribution of authors}

We declare that this work was done by the authors named in this article and all liabilities pertaining to claims relating to the content of this article will be borne by the authors.

\section{Open Access}

This is an Open Access article that uses a funding model which does not charge readers or their institutions for access and distributed under the terms of the Creative Commons Attribution License (http://creativecommons.org/licenses/by/ 4.0) and the Budapest Open Access Initiative (http://www.budapestopenaccessinitiative.org/rea d), which permit unrestricted use, distribution, and reproduction in any medium, provided the original work is properly credited.

\section{REFERENCES}

1. Aggarwal A, Lewison $G$, Idir $S$, Peters $M$, Aldige $C$, Boerckel W, Boyle P, Trimble EL, Roe P, Sethi $T$, et al. The state of lung cancer research: A global analysis. J Thorac Oncol 2016; 11: 1040-1050.

2. Lemjabbar-Alaoui H, Hassan OU, Yang YW, Buchanan P. Lung cancer: Biology and treatment options. Biochim Biophyc Acta 2015; 1856(2): 189-210.

3. McIntyre A, Ganti AK. Lung cancer-A global perspective. J Surg Oncol 2017; 115(5): 550-554.

4. Zappa C, Mousa SA. Non-small cell lung cancer: current treatment and future advances. Transl Lung Cancer Res 2016; 5(3): 288-300.

5. Fu JB, Kau TY, Severson RK, Kalemkerian GP. Lung cancer in women: Analysis of the national surveillance, epidemiology and end results database. Chest 2005; 127: 768-777.

6. Alberg AJ, Wallace $K$, Silvestri GA, Brock MV. Invited commentary: The etiology of lung cancer in men compared with women. Am J Epidemiol 2013; 177: 613616.

7. Schiller JH, Harrington $D$, Belani $C P$, Langer $C$, Sandler A, Krook J, Zhu J, Johnson DH. Eastern Cooperative Oncology Group: Comparison of four chemotherapy regimens for advanced non-small-cell lung cancer. $N$ Engl J Med 2002; 346: 92-98.

8. Cerfolio RJ, Bryant AS, Scott E, Sharma M, Robert F, Spencer SA, Garver RI. Women with pathologic stage I, II, and III non-small cell lung cancer have better survival than men. Chest 2006; 130: 1796-1802.
9. Hsieh TC, Ng CH, Chang CC, Chen SS, Mittleman A, Wu JM. Induction of apoptosis and down-regulation of bcl-6 in mutu I cells treated with ethanolic extracts of the Chinese herbal supplement PC-SPES. Int J Oncol 1998; 13(6): 1199-1202.

10. Schultze JL, Stettin A, Berg PA. Demonstration of specifically sensitized lymphocytes in patients treated with an aqueous mistletoe extract (Viscum album L.). Klinische wochenschrift 1991; 69(9): 397-403.

11. Hajto T, Hostanska K, Gabius HJ. Modulatory potency of the $\beta$-galactoside specific lectin from mistletoe extract (Iscador) on the host defense system in vivo in rabbits and patients. Cancer Res 1989; 49(17): 4803-4808.

12. Elsässer-Beile U, Lusebrink $S$, Grussenmeyer $T$, Wetterauer U, Schultze-Seemann W. Comparison of the effects of various clinically applied mistletoe preparations on peripheral blood leukocytes. Arzneimittel-forschung 1998; 48(12): 1185-1189.

13. Prasad S, Aggarwal BB. Turmeric, the golden spice: from traditional medicine to modern medicine. Herbal medicine: Biomolecular and clinical aspects. 2011; 13.

14. Katsidoni V, Alexiou $P$, Fotiadou $M$, Pelecanou $M$, Sagnou M, Panagis G. Curcumin, demethoxycurcumin and bisdemethoxycurcumin differentially inhibit morphine's rewarding effect in rats. Psychopharmacology 2014; 231(23): 4467-4478.

15. Leng L, Zhong $X$, Sun G, Qiu W, Shi $L$. Demethoxycurcumin was superior to temozolomide in the inhibition of the growth of glioblastoma stem cells in vivo. Tumor Biol 2016; 37(12): 15847-15857.

16. Rahmani S, Asgary S, Askari G, Keshvari M, Hatamipour M, Feizi A, Sahebkar A. Treatment of non-alcoholic fatty liver disease with curcumin: $A$ randomized placebocontrolled trial. Phytother Res 2016; 30(9): 1540-1548.

17. Lim DW, Son HJ, Um MY, Kim IH, Han D, Cho S, Lee $\mathrm{CH}$. Enhanced cognitive effects of demethoxycurcumin, a natural derivative of curcumin on scopolamine-induced memory impairment in mice. Molecules 2016; 21(8): 1022.

18. Munigunti R, Gathiaka S, Acevedo O, Sahu R, Tekwani $B$, Calderón Al. Determination of antiplasmodial activity and binding affinity of curcumin and demethoxycurcumin towards Pf TrxR. Nat Prod Res 2014; 28(6): 359-364.

19. Khursheed A, Rather MA, Rashid R. Plant-based natural compounds and herbal extracts as promising apoptotic agents: their implications for cancer prevention and treatment. Adv Biomed Pharma 2016; 3(04): 245-69.

20. Elmore S. Apoptosis: a review of programmed cell death. Toxicol Pathol 2007; 35(4): 495-516.

21. Ouyang L, Shi Z, Zhao S, Wang FT, Zhou TT, Liu B, Bao JK. Programmed cell death pathways in cancer: a review of apoptosis, autophagy and programmed necrosis. Cell Prolif 2012; 45(6): 487-98.

22. Lin HY, Lin JN, Ma JW, Yang NS, Ho CT, Kuo SC, Way TD. Demethoxycurcumin induces autophagic and apoptotic responses on breast cancer cells in photodynamic therapy. J Funct Foods 2015; 12: 439449.

Trop J Pharm Res, April 2021; 20(4): 692 
23. Ni $X$, Zhang A, Zhao $Z$, Shen $Y$, Wang $S$. Demethoxycurcumin inhibits cell proliferation, migration and invasion in prostate cancer cells. Oncol Rep 2012; 28(1): 85-90.
24. Borges GA, Elias ST, Amorim B, de Lima CL, Coletta RD, Castilho RM, Squarize $\mathrm{CH}$, Guerra EN. Curcumin downregulates the PI3K-AKT-mTOR pathway and inhibits growth and progression in head and neck cancer cells. Phytother Res 2020. 